"Biographical Memoir of Chas. A. Schott," Cleveland Abbe.

"The Distribution of the Recent Crinoids," Austin H. Clark (introduced by Theo. Gill) .

"On the Distribution of Energy in the Spectrum of the Light from Fluorescent Substances," E. L. Nichols and Ernest Merritt.

"A Geographical Excursion in Northern Italy," W. M. Davis.

\section{THE AMERICAN SOCIETY OF NATURALISTS}

THE annual meeting of the American Society of Naturalists was held in the auditorium of the Physiological Building, Johns Hopkins Medical School, Baltimore, Md., December 31, 1908. Fiftyfive members were present.

On vote of the society the address of the retiring president, Professor D. P. Penhallow, in his absence, was read by the chairman, Professor T. H. Morgan. It is printed herewith.

A discussion of the functions and relations of the society followed, participated in by delegates from some of the affiliated societies and by Professors Minot, Davenport, Baldwin and Cattell. This resulted in an emphatic vote in favor of preserving the integrity of the society and of establishing a more effective cooperation between its sections. Professor C. B. Davenport offered a motion that the constitution be amended so that the executive committee of the Naturalists be composed of the secretaries of Sections F, G and $\mathrm{K}$ of the American Association and of the secretaries of the technical biological societies affiliated with the Naturalists, the same to form a program committee for the arrangement of papers, times and places of meeting, etc. This motion was referred to the executive committee with power to act.

Professor T. H. Morgan, on behalf of the executive committee, moved first that the study of evolution be the general policy of the society for the ensuing year; second, that the program consist of original contributions on the subject of evolution and of reports, demonstrations, etc., of important recent work in this field. The society voted to adopt this program for the current year. Members from the affiliated societies are accordingly requested to reserve contributions bearing on this topic for presentation before the Naturalists at the next annual meeting.

The place and time of the next meeting was referred to the executive committee.

Eleven new members were elected; they are: D. S. Johnson, Johns Hopkins University; R. C.
Osburn, Barnard College; G. G. Scott, College of City of New York; A. H. Clark, National Museum; L. L. Woodruff, Yale University; N. E. Kellicott, Woman's College of Baltimore, Md.; R. P. Cowles, Johns Hopkins University; J. F. McClendon, University of Missouri; F. B. Sumner, Woods Hole; A. A. Budington, Oberlin College; R. Retzer, Johns Hopkins Medical School.

At an adjourned meeting in the evening the following officers were elected for this year:

President-Professor T. H. Morgan, of Columbia University.

Vice-president and Chairman of the Eastern Section-Professor W. H. Howell, Johns Hopkins University.

Additional Members of the Council-Dr. D. T' MacDougall and Professor Charles H. Judd.

Treasurer-Dr. Herman von Schrenck.

Secretary-Dr. H. McE. Knower.

Professor R. A. Harper, University of Wisconsin, is vice-president and chairman of the Central Branch of the society, and Professor J. G. Lee, University of Minnesota, is secretary of the Central Branch.

H. MoE. KNower, Secretary

\section{REPORT OF THE BALTIMORE MEETING OF THE AMERICAN FEDERATION OF TEACHERS OF THE MATHEMATICAL AND THE NATURAL SCIENCES}

THE council of the federation met in Baltimore, Md., on Monday, December 28, at 3 P.M. Of the thirty-three members of the council, nineteen were present either in person or by proxies. The report of the executive committee, presented by Mr. J. T. Rorer, outlined the work of the year in connection with organization, the appointment of a special committee on the bibliography of science teaching, the issue of the November Bulletin, and preparations for the council meeting in Baltimore. It pointed out some of the specific questions which might naturally engage the attention of the officers of the federation during the coming year; emphasizing, however, the dependence of successful work on increased financial resources.

The treasurer reported a balance of $\$ 20.20$ from last year, as shown in the printed statement in the Bulletin. The printing and mailing of the Bulletin had cost $\$ 53.00$, leaving $\$ 32.80$ chargeable to this year's account. Dues from the federated associations for this year had not yet been collected. An auditing committee, consisting of Messrs. L. S. Hulbert and C. H. Smith, was ap- 
pointed, and reported later that the accounts were correct.

Interesting reports in regard to organization and methods of work were presented from the following local societies: The Association of Mathematical Teachers in New England, presented by Mr. W. T. Campbell; The Association of Teachers of Mathematics of the Middle States and Maryland, presented by Mr. Eugene R. Smith; The Physics Club of New York, by Mr. F. B. Spaulding; The Association of Biology Teachers of New York, by Mr. G. W. Hunter; The Association of Physics Teachers of Washington, D. C., by Mr. W. A. Hedrick; The New England Association of Chemistry Teachers, by Mr. H. P. Talbot; The Central Association of Science and Mathematics Teachers, by Mr. C. H. Smith; 'The Colorado Mathematical Society, by Mr. G. B. Halsted; The Southern California Science Assoeiation, by Miss T. A. Brookman. All the reports showed active and constructive work under way.

By unanimous consent the following article was added to the articles of federation as adopted at the Chicago meeting:

13. These articles may be amended at any annual meeting of the council by a two thirds vote of the members present provided notice of the proposed amendment has been sent to all members of the council and to the president and secretary of each federated society at least thirty days prior to the meeting.

The following resolutions were unanimously passed:

Resolved, That it is the sense of the American Federation of Teachers of the Mathematical and the Natural Sciences that larger appropriations should be made by Congress for the support of the United States Bureau of Education so as to enable it greatly to increase the scope and inportance of its work and to render immediate and effective aid in the promotion of education in the mathematical and the natural sciences; and

Resolved, That the executive committee of the federation be authorized to take such action as may seem to it desirable to further such action by Congress.

Three committees of the federation were authorized as follows: One on a syllabus of propositions in geometry; one on publication and publicity, to report next year on the present needs and facilities for publishing material of interest to the federation, and to make recommendations as to ways and means of improving these facilities; one to investigate the present conditions of college entrance, to define the attitude of the federation towards college entrance problems, and to recommend action that may tend to unify and simplify college entrance requirements.

The following were elected officers for the coming year:

President-H. W. Tyler, Massachusetts Institute of Technology.

Secretary-treasurer-C. R. Mann, University of Chicago.

Other Members of the Executive CommitteeG. W. Hunter, DeWitt Clinton High School, New York; J. T. Rorer, Central High School, Philadelphia; C. H. Smith, Hyde Park High School, Chicago.

Professor R. E. Dodge presented a report of progress from the committee on bibliography, showing that the sections on mathematics, physics, biology and geography were nearly completed.

A letter from Professor D. E. Smith, representing the International Commission on the Teaching of Mathematics, was presented, expressing the hope that the federation would cooperate in its undertaking in due time.

On Tuesday morning, December 30, the federation held a joint session with Section L, Education, of the American Association for the Advancement of Science. The topic, "The Problems of Science Teaching," was discussed by President Ira Remsen and Messrs. G. F. Stradling (Philadelphia), Wm. T. Campbell (Boston), John M. Coulter (Chicago), N. M. Fennemann (Cincinnati) and Lyman C. Newell (Boston), as follows: President Remsen said:

"A battle that has long been waging has been won-the battle for the recognition of science in the courses of study in schools and colleges. I remember well my first experience as a teacher of chemistry. I had accepted a position in one of the small New England colleges without having examined the equipment. When I arrived in the fall ready to begin work, I found that the institution did not possess a laboratory. I at once applied to the president for one, and he replied: 'What for? I have taught chemistry, and I thought successfully, without a laboratory; and if I could do it, I think you can. This is not a technical school; what the students want is the broad general principles of chemistry.' So I tried to teach without a laboratory. I was wholly unsuccessful; the students learned nothing-in 
fact, some of them told me so in later years. The experience was, however, very useful to me, for I learned a great deal from it.

"Now science is recognized; we have laboratories everywhere and laboratory training is regarded as indispensable. It is therefore fitting to ask: What are we doing with our facilities? What results are we obtaining? When the battle was on, men lost their heads-men must lose their heads in order to fight. We thought that if only we could get laboratories, the problems of education would be solved. Is this true?

"Pedagogical problems are hard to solve-it is" very difficult to get sound conclusions. How can we tell whether the scientific training is more effective than that of the older type? This is a problem that can not be solved by sitting down and thinking about it; it can be solved only by research and experiment. I do not myself know whether scientific training as now conducted is producing the results hoped for. Yet I am convinced that scientific training, when properly conducted, may be of the greatest value as an educational force. This is quite a different thing from saying that that particular thing now known as science training is of great value. It all depends upon how it is done.

"Personally, I have been guilty of all the sins possible for a teacher of science. I have been experimenting to find out how to teach chemistry; and it is the most difficult experiment $I$ have ever tried. My own experience in school was very instructive to me, for my own education was most unsatisfactory-in fact, 1 never was educated. My first experience with chemistry was gained in a course of lectures one hour a week by one of the greatest chemists of this country, Professor Wolcott Gibbs. Yet from this course I learned nothing. My second experience came when I had taken up the study of medicine. The teacher knew little chemistry, and I was asked to assist him in preparing the experiments for his lectures. He had a large practise, and left me alone to prepare experiments that I had never seen. I am almost ashamed to confess what happened that year-there were explosions and fires and bungling beyond words. I had little or no guidance.

"In my first course the instruction had been 'theoretical'; in the second I had the 'practical' galore; I therefore thought I was an experienced chemist and could go on and take an advanced course. It was a sad awakening when
I found that I knew practically nothing of the subject.

"But to return to our theme: Are we doing the best that is possible with what we now have? Do the results obtained justify the equipment and time devoted to scientific study? I am not qualified to answer these questions for the schools; but speaking for the colleges, I may say that, in my opinion, the results are frequently quite unsatisfactory. The reason is that we have not yet learned how to deal with the subject. It is not hard to teach chemists chemistry, but it is very hard to teach beginners something that is worth while about chemistry in one year. What can be expected of a one-year course? Have you ever seen students who obtained an intelligent knowledge of any subject in one year? We can not expect anything of great value in that limited time. If getting knowledge of a subject is the purpose, we can not expect much of even the best teachers. But the important point is: Are we doing the best we can under the circumstances?

"There are two points in which, it seems to me, we might do better-two defects that might be remedied. One defect is that the student is not subject to enough supervision in his laboratory work. He is very much in the condition in which I found myself when turned loose in the laboratory to prepare experiments I had never seen, $\mathrm{He}$ is turned loose with a book, and then left alone. This is not conducive to scientific work. School authorities do not realize the need of enough teachers for the sciences. The head teacher generally expounds the subject and leaves the laboratory work to inexperienced assistants. It is too much work for the professor to have to spend four or five hours a day in the laboratory with the students. If we could get teachers with interest in their subject and in their students, it would solve the problem; but in science as in other subjects, we are not going to find these often. Unless we can find out how to produce good teachers, we shall fail to get the best results.

"The second important defect in the present teaching of chemistry in college is the absence of repetition. There are too many fleeting impressions. There is a little about a great number of things, as oxygen, hydrogen, chlorine, nitrogen, phosphorus-each being treated as something new with no reminders. In language there is much repetition; each new lesson continually connects with past work. Yet it is only by repetition that we learn. We do not learn a game by being told 
how to play and then trying it once. Repetition is largely lacking in science teaching. We cover too much ground. The student gets only a veneer.

Knowledge of this sort is not of much use, and the drill given by such study is not effective. We must introduce into science teaching the drill element that comes only from repetition of the sort that is characteristic of languages and mathematics.

"Chemistry has one kind of work involving repetition of the right sort, namely, qualitative analysis. This field offers good educational possibilities, but the work is in great danger of becoming mechanical. The student is prone to go through the motions with his mind on his book, to guess at the results, to report, watching the reaction of the teacher closely, and to get credit. In order to introduce this element of repetition, quantitative work has been introduced to save the situation. Some quantitative work is desirable. It makes it possible to keep a student at one experiment till he has obtained good results. Such work is monotonous, though it has the advantage of not requiring the student to cover too much ground.

"The remedy for these two important defects is, unfortunately, unattainable at present. We must get good teachers. Much is being done in the way of training teachers, and much that is good is coming from this work. Yet we must not forget that good teachers are not easily made. It is harder to train a teacher to conduct laboratory work efficiently than to train one to teach mathematics or a language. In science the laboratory presents a new problem, and serious errors have occurred and are occurring. Yet, in spite of this, great progress is being made, and there is little doubt that in the end scientific training will fully justify itself in the schools and colleges.

"In closing let me again specifically state that 1 do not consider myself competent to speak of science training in the secondary schools; all that I have been saying applies, as far as my own definite knowledge goes, only to the colleges."

Dr. G. F. Stradling showed that there has been no notable change within the past decade in the relation of doctorates in physics to the whole number conferred in the United States, nor has any notable change in the proportion of students offering physics upon entrance to college taken place. There has, however, been a very marked decrease in the percentage of all high school students taking physics.
From 1890 to 1906 the high school population became two and three fourths times as great, while the number of students of physics merely doubled. Had the ratio of 1890 held unchanged, 49,000 more students would have been studying physics in the high schools in 1906. In 1890 about 21.3 per cent. of all high school students studied physics, in 1906 only 15.5 per cent. For chemistry the numbers are 9.6 and 6.8. Every year since 1894, without exception, has shown a smaller percentage of students in physics.

From 1890 to 1906 the percentage of Latin students grew from 33.6 to 50 per cent.; of German students, from 11.5 to 21 per cent.; of algebra students, from 43 to 57.6 per cent.

Chemistry, astronomy, physiology, reology and physical geography all are losing grouna in the high school. The sum of the percentages of students in these branches and in physics in the period named fell from 93 to 67 per cent., while the sum for Latin, Greek, French and German rose from 71 to 84 per cent.

Causes suggested for these changes were: (1) introduction of a wider system of electives; (2) lack of well-prepared teachers, and (3) change in the method of teaching.

A commission of the caliber of the committee of ten ought to investigate thoroughly tne conditions of science teaching in the United States. An increased appropriation from Congress to the Bureau of Education would help to bring about such an investigation.

Mr. William T. Campbell, of the Boston Latin School, claimed that more attention is needed to the care of students of average mathematical ability. Under the elective system these drift into other paths. Something has been done to make the subject more attractive to them; but more remains to do. It is doubtful whether our present course, even if improved, will meet the situation. Considerable change in the direction of practical work and of closer connection with other sciences is needed.

Professor Coulter pointed out that, while the problems of the teaching of botany were constantly changing, those at present most urgent seem to be: (1) to get the prepared teacher who has a general knowledge of the fundamentals of botany, clear conceptions of the purpose of botany in the secondary schools as distinguished from higher institutions, and ability to attack the subject in a variety of ways; (2) the place of economic 
botany or agriculture in the botanical instruction; (3) the biological grouping of subjects; (4) the holding of the interest of the students, $i$. $e$, the finding of the effective point of contact for botany with students who are looking for practical values. No formulation of the value of botany can be made until these problems have been settled. The time is now ripe for a well-organized investigation, to be followed by a statement of well-established conclusions.

A full report of the meeting will be issued in pamplet form early in May. This will be sent to the members of the federation. Any one may obtain copies by applying to the secretary.

\section{R. MANN,} Secretary

\section{The University of Chicago}

\section{THE AMERICAN ASSOCIATION FOR THE $A D V A N C E M E N T$ OF SCIENCE SECTION F (ZOOLOGY)}

THE vice-presidential address at the Baltimore meeting was delivered by Professor E. B. Wilson. It was published in ScIence, January 8, 1909.

The secretary has received abstracts of papers read as follows:

Brood-protection and Sexual Dimorphism among

Echinoderms: Hubert LyMaN Clark, Harvard University.

The large number of echinoderms now known (about fifty) which protect or care for their young in some way show great diversity in the method used. The eggs may develop outside the body of the parent or more rarely within the bodycavity or in special reproductive cavities. If developed outside the body, the young may become attached to some part of the parent, or be sheltered among her spines or covering plates, or simply be brooded beneath her ventral surface. If developed within the parent, the young may swim about freely in the body-cavity, or more rarely undergo their development in the repro. ductive organs, which are thus practically uteri.

Among all these brood-protecting species, however, there seem to be only half a dozen (about twelve per cent.) which occur in tropical waters, while more than sixty per cent. are found in Antarctic or South Temperate seas.

Only four species, and these all from between $30^{\circ}$ and $60^{\circ} \mathrm{S}$. latitude, show any marked sexual dimorphism. In one, an ophiuran, the male has only five arms, the female, six to eight (Koehler). In another, a holothurian, the development of a peculiar brood-chamber in the dorsal integument distinguishes the female. The third is a spatangoid in which the lateral petals of the female are much broader and deeper than those of the male and serve as brood-pouches. The fourth is a clypeastroid, recently discovered in the Australian collections of the "Thetis," in which the abactinal area of the female is deeply depressed to form a horseshoe-shaped brood-chamber, wholly wanting in the male.

Notes on the Eggs of the Anura of Ithaca, N. Y.: Albert H. Wright, Cornell University.

Eight species of Anura are found at Ithaca, N. Y., namely: Rana sylvatica, Hyla pickeringii, Rana pipiens, Bufo lentiginosus americanus, Rana palustris, Hyla versicolor, Rana clamitans and Rana catesbiana.

The first five species appear from hibernation and spawn under a maximum air temperature of $43-50^{\circ} \mathrm{F}$.; the last three delay until the maximum reaches $70^{\circ} \mathrm{F}$. or more. The first five usually breed from the last of March until the middle of June; the last three, from the last of May into August. All but two species, Bufo $l$. americanus and Rana clamitans, occupy four or five weeks for the spawning period. The exceptions may require two or three months. The number of eggs may vary from 800 in Hyla pickeringii to 20,000 in Rana catesbiana.

The eggs of three species, Hyla versicolor, Rana clamitans and Rana catesbiana, float more or less at the surface of the water; the eggs of the other five are submerged. The five species with submerged eggs are the first to breed. They deposit eggs with firm jelly envelopes, several eggs appearing at an emission except in Hyla pickeringii, where only one appears at an emission. The three with buoyant eggs breed after May 25. They depoisit at the surface masses or films of eggs with loose jelly envelopes, several eggs being deposited at an emission. The best differential egg characters are: the manner of deposition, the nature of the jelly envelopes, the color of the vitellus, the diameters of the vitellus and jelly envelopes, the number of eggs and the season of deposition.

Factors Determining the Movement of Melanin Pigment Granules: OscaR RIDDre, University of Chicago.

Movement of these particles from one part of the cell plasma to another, and from one cell to another, is probably determined either by the solubility properties or by the electrical state of the granules. Author obtained no evidence of solubility. The granules are, however, definitely proven to be colloidal bodies bearing a negative 